\title{
ÖĞRETEN OKULLARIN TAMAMLAYICISI: ÖĞRENEN OKULLAR $^{*}$ \\ COMPLEMENT OF TEACHING SCHOOLS: LEARNING SCHOOLS
}

\author{
Soner DOĞAN** \\ Yakup YİĞITT**
}

\section{$\ddot{O} \mathbf{z}$}

$\mathrm{Bu}$ çalışmanın amacı, okul yöneticilerinin ve öğretmenlerin algılarına ve görüşlerine göre öğrenen okul kavramının incelenmesidir. Araştırmada, nicel ve nitel yöntemleri içerisine alan açıklayıcı (explanatory) desen kullanılmıştır. Araştırmanın nicel bölümü ilişkisel tarama modelinde desenlenmiş olup veriler, Sivas ilinde görev yapan 336 okul yöneticisi ve öğretmenden, Öğrenen Okul ölçeği aracılığıyla toplanmıştır. Araştırmanın nitel bölümü ise durum desenine uygun olarak yürütülmüş, nitel veriler Sivas ilinde görev yapan 10 okul yöneticisi ve öğretmenden yarı yapılandırılmış görüşme formu aracılığıyla elde edilmiştir. Araştırma sürecinde tüm görüşmeler ses kayıt cihazıyla kayıt altına alınmıştır. Görüşme verilerinin yorumlanması sürecinde betimsel analiz, içerik analizi ve sürekli karşılaştırma tekniği kullanılmıştır. Yapılan analizler sonucunda elde edilen bulgular dört tema altında yapılandırılmıştır. Araştırmanın nicel bulguları okul yöneticileri ve öğretmenlerin öğrenen okul algılarının yüksek düzeyde olduğunu gösterirken nitel bulgular nicel bulguları desteklememektedir.

Anahtar Kelimeler: Organizasyon, Okul Yöneticisi, Öğretmen, Öğrenen Okul, Görüşme

\begin{abstract}
The aim of this study is to examine the concept of learning schools according to the perceptions and opinions of school administrators and teachers. In the research, the explanatory research design that included quantitative and qualitative methods was used. The quantitative part of the study was designed in relational screening model and the data were collected through the Scale of Learning School from 336 school administrators and teachers who work in Sivas. Besides, the qualitative part of the research was carried out in accordance with the case design and the qualitative data were obtained through semi structured interview form, from 10 school administrators and teachers who work in Sivas. During the research process, all interviews were recorded with a tape recorder. In the interpretation process of the interview data; descriptive analysis, content analysis and constant comparative methods were used. The findings of the analyses carried out were examined under four themes. While quantitative findings of the research show that the perceptions of school administrators and teachers on learning school are at a high level, the qualitative findings do not support the quantitative findings.
\end{abstract}

Key Words: Organization, School Administrator, Teacher, Learning School, Interview

\footnotetext{
${ }^{*}$ Bu çalışmanın nicel verileri Yrd. Doç. Dr. Soner DOĞAN danışmanlığında Yakup YiĞiT tarafından yapılan yüksek lisans tezinden alınmıştır.

${ }^{* *}$ Yrd.Doç.Dr. Cumhuriyet Üniversitesi Eğitim Fakültesi Eğitim Bilimleri Bölümü, snr312@gmail.com

*** MEB, yakupyigit58@hotmail.com
} 


\section{GíRiş}

Bilginin en önemli güç olarak kabul edildiği çağımızda; bilginin elde edilmesinde, geliştirilmesinde ve aktarılmasında öğrenme etkili bir süreç olarak ön plana çıkmaktadır. Öğrenebilen bireyler, öğrenme kültürüne sahip örgütler ve öğrenmeyi teşvik eden sistemler bilgi çağının sürükleyici güçleri olmuşlardır. Alipour ve Karimi'e (2011) göre günümüzde örgütler performanslarını arttırabilmek için bilgiyi kullanmaya ve sürekli öğrenmeye odaklanmaktadırlar. Bu bağlamda Aybar (2011) hızla değişmekte olan dünya içerisinde öğrenen örgütlerin ve bireylerinin, yeni prensiplere göre hareket edilerekgeliştirilmesi gerektiğini ifade ederken Özus (2005), Çoban (2006), Pekel (2007) ve Koçel (2005) bireysel öğrenmeden çok takım halinde, birlikte öğrenme faaliyetlerine ağırlık verilmesinin önemine vurgu yapmışlardır. Bu nedenle Mohanty ve Kar (2012)örgütler yeniliklerin tecrübe edildiği ve çalışanların yetkinliklerinin geliştirildiği bir öğrenme kültürü oluşturmalı ve Kerman, Freundlich, Lee ve Brenner (2012) öğrenen örgüt idealini gerçekleştirmeye çalışmalıdır.

Birçok disiplinin çalışma alanına giren örgütsel öğrenme (Aybar, 2011) ekonomik büyümenin bilgiye dayalı bir güçle sağlanmaya başlanmasından sonra giderek popüler olmaya başlamıştır (Tee, 2004). Öğrenen örgüt kavramının 1970'lerde ortaya çıktığ1, 1978 yılında Argyris ve Schon tarafından yapılan çalışmalardan türetildiği, aynı zamanda 1983 yılında Revans tarafindan yapılan çalışmalarla ilişkili olduğu söylenebilir. Ancak kavramın tam olarak duyurulması 1990 yılında Senge'nin hızla değişen modern dünyaya adapte olabilmek için örgütsel sorumlulukların öncelikle eğitim ve öğrenme olması gerektiği üzerinde odaklanan (Hawamdeh ve Jaradat 2012) Türkçe'ye "Beşinci Disiplin" olarak çevrilen "Fifth Discipline" adlı kitabıyla olmuştur(Bakan, 2011). Senge'nin beş disiplini ise bireylere ortak bir kimlik kazandırarak onları kader arkadaşlı̆̆ duygusu içerisine alan, bireylerin belli bir amaç etrafında birleşmesini sağlayan ve öğrenen örgütler için hayati öneme sahip olan "paylaşılan amaç ve vizyon" (Bakan, 2011; Subaş, 2010); parçaya değil bütüne odaklanan, tek tek fotoğraflara değil resmin tamamını görebilen hatta değişim noktalarına, sorunların kaynaklarına kadar inebilen "sistem düşüncesi" (Şimşek ve Kıngır, 2006); kişisel gelişim ve öğrenme odaklı olan, kişinin ufkunu sürekli derinleştiren, tahammül gücünü geliştirerek olayları objektif görebilmesi becerisini artıran (Akat ve Budak, 2002), bireylerin yeteneklerinin sınırsız kullanımının söz konusu olduğu "kişisel hakimiyet" (Şanal, 2009); bireysel zekalardan daha üstün kolektif bir zekanın hâkim olduğu ve temel öğrenme biriminin bireylerin öğrenmesi değil takımların öğrenmesi olan "takım ile öğrenme" (Efil, 2002); bireylerin zihinlerinde kalıplaşmış kabullenmeleri içeren, dünya algıları, bakış açıları olarak tanımlanabilen(Bakan, 2011), zaman zaman öğrenmeyi engelleyebilen ve değişimi kısıtlayabilen "zihni modeller" (Kılıç, 2009) olarak açıklanabilir.

Öğrenen Örgüt, problem çözme temeline dayalı yapısıyla, etkinlik amaçlı tasarlanmış geleneksel örgütten farklılaşmaktadır (Akhtarve Khan, 2011). Öğrenen örgütü diğer örgütlerden farklılaştıran "öğrenme" faaliyetinin işin her tarafına yayılmasıdır. Öğrenme için ayrı bir zaman dilimi belirlemek yerine örgütteki bireylerin her türlü etkileşiminde (iş birliği, iş bölümü) öğrenme bir sürece dönüşmektedir (Braham, 1998). Yeni bilgi temelli ekonomi ve öğrenen toplumun talepleri doğrultusunda öğrenen örgüt rüyası gerçekleşmiştir. Geleneksel kuruluşlar öğrenen örgütleri anlamak ve kendilerini bu tür örgütlere dönüştürebilmek için çaba sarf etmektedirler. Bu kapsamda örgüt içerisinde yenileşme, farklı bakış açılarını yakalama, her soruna ilişkin özgün problem çözme yöntemleri kullanma, amaçlara ulaşmada niteliğin artırılması, paylaşılan vizyon oluşturulması gibi unsurlar aracılığıyla örgüt adım adım yeniden yapılandırmaya doğru götürülmektedir (Mohanty ve Kar, 2012, s. 36). Öğrenen örgütün sağlıklı bir şekilde yapılandırılabilmesi, örgüt liderlerinin öğrenen bir organizasyonu arzulaması (Şimşek ve Kıngır, 2006),organizasyonların değişimlere cevap verebilme ve yeni sistemler geliştirebilmeleri (Turan, 2011), bilginin toplanması, değerlendirilmesi ve 
kullanılması (Akat veBudak, 2002), ulaşılan sonuçların örgüt bilgisi haline getirilmesi, sorunların çözülmesi (Koçel, 2001), bireylerin yeniliklere esneklik gösteren, vizyon belirleyen bir konuma gelmesi (Eren, 2010), örgütün bilgi kazanması (Töremen, 2011),sürekli öğrenme mekanizmasının aktif hale getirilmesi (Bejinaru ve Lordache, 2011), tüm örgüt üyelerinin kapasitelerinin sonuna kadar kullanılması(Senge, 1990), geleceğin inşa edilmesi için sürekli kapasitenin geliştirilmesi (Mohanty ve Kar, 2012) ve bilgi ile iş gören arasındaki ilişkinin kurulması (Srihawong ve Srisa-Ard, 2012) ile gerçekleştirilebilir.

Eğitim kurumları, günümüz toplumu tarafından dayatılan rekabetçi ortamda rekabet gücü kazanma, etkinliklerini ve verimliliklerini arttırma yollarını aramaktadırlar. Bu nedenle okullar çevrelerindeki değişimleri takip etmeli ve bu değişimlere uyum sağlamalıdır. Bunun için tek yol ise okulların geleneksel eğitim anlayışını terk ederek öğrenen örgütlere dönüşmeleridir (Jokić, Ćosıc, Sajfert, Pečujlija ve Pardanjac, 2012). Bu bağlamda okullarıntam bir öğrenen örgüt yapısına kavuşmasını, içinde bulunulan çevre şartlarının zorunlu kıldığ1 söylenebilir (Lyle, 2012). Literatüre göre öğrenen okullar, çevresinde gelişen süreçleri takip eder, amaçlarını geliştirir, elverişli bir öğretme ve öğrenme ortamı oluşturur, girişimcilik ve risk alma konusunda cesaretlendirir, okuldaki çalışmaları etkileyen tüm konularda düzenli analizler yapar ve okulun profesyonel gelişiminin devamlılığını sağlamak için firsatlar oluşturur (Jokıć ve ark. 2012). Bu noktadaöğrenen okulun öğretmen ve öğrencileri ile tek başına ulaşılması zor olan bilgilerin takım ruhu ile kolay öğrenilebilir ve kullanılabilir bir yapıya dönüştürülmesinde öncülük edeceği düşünülmelidir. Okullarda bireylerin sürekli öğrenme ve gelişmeye açık neferler olarak yetişmelerine özen gösterilmelidir. Öğrenme ayrı bir zaman ayrılarak yapılan bir faaliyet olmaktan öteye geçip bir yaşam tarzı haline gelmelidir (Subaş, 2010). Bu aşamadaki okullarda yaratıcılık ve sürekli öğrenme had safhada olup bilgi bireyler arasında paylaşılmaktadır (Boztepe, 2007).

Okulların öğrenen örgüt olabilmesi için öncelikle örgütsel öğrenme kültürüne sahip olmaları gerekmektedir Öğrenen okul bir öğrenme laboratuarı olarak anlaşılmalıdır. Bu tip okullarda öğretmenler ve diğer paydaşları kendi alanlarındaki yenilik ve değişimleri sürekli takip eder ve meslektaşlarıyla paylaşırlar(Şimşek ve Yıldırım, 2004). Bu bağlamdaokullara bir takım olarak bakıldığında okul yöneticilerinin okul başarısını tüm takıma mal etmesi, kolektif zekâyı etkin bir duruma getirebilir (Efil, 2002). Bunun için okullarda karara katılma ve sorunlara dönük sik sik toplantıların gerçekleştirildiği bir yapının oluşturulması (Alp, 2007),okulun dinamik yapısı ile öğretmenlerin tutumları arasında bağ kurulması (Schechter ve Qadach, 2012), nihai hedefin öğrencilerin öğrenmesi olarak belirlenmesi (Wayneve Cecil, 2010), bilginin üretilmesi kadar paylaşılması, yorumlanması ve kullanılması (Jillinda, Kidwell, Vander ve Sandra, 2000) ve okullardaki informal yapılarla birlikte sosyal etkileşimin sağlanması (Ferraria ve Pulecio, 2012) gerekmektedir.

Alanyazına bakıldığında, öğrenen örgüt kavramının ağırlıklı olarak işletme bilimi içerisinde öğrenen organizasyonlar (Akkoç, 2008; Atak, 2009; Aybar, 2011;Çetinel, 2011; Çoban, 2006; Pekel, 2007; Şakinkesen, 2010); konu eğitim kurumları içerisinde ele alındığında ise çoğunlukla öğrenen örgüt(Alp, 2007; Bal, 2011; Banoğlu, 2009; Eğmir, 2012; Ergani, 2006; Yıldız, 2011;Özus, 2005) başlıkları altında incelendiği görülmektedir. Öğrenen okul başlığı altında yapılan çalışmalar ise (Boztepe, 2007; Forozandeh, Soleimani, Nazari ve Nasri, 2011; Jokıć ve ark., 2012; Subaş, 2010) sinırlı sayıda bulunmaktadır. Bu bağlamda, daha çok işletme tipi örgütlerde kullanılan öğrenen örgüt ve öğrenen organizasyon kavramlarının kendine özel yapısı ile işletme tipi kurumlardan ayrılan eğitim kurumlarında öğrenen okul kapsamı içerisinde incelenmesi, eğitim kurumlarının öğrenen okul olma yolunda dönüştürülmesi ve öğrenen okul kavramı hakkında eğitim paydaşlarının farkındalık düzeylerinin arttırılması önem arz etmektedir. 
$\mathrm{Bu}$ kapsamda araştırmanın amacı, okul yöneticilerinin ve öğretmenlerin algılarına ve görüşlerine göre öğrenen okul kavramının incelenmesi, araştırma bulgularına dayanılarak eğitim kurumlarının öğrenen okula dönüştürülmesi sürecine katkı sağlamaktır. Araştırma da aşağıdaki sorulara yanıt aranacaktır:

1- Okul yöneticilerinin ve öğretmenlerin öğrenen okula ilişkin algıları ne düzeydedir?

2- Okul yöneticilerinin ve öğretmenlerin öğrenen okula ilişkin algılarıcinsiyet, görev, yaş, okul türü ve kıdem değişkenlerine göre ne düzeydedir?

3- Okul yöneticilerinin ve öğretmenlerin öğrenen okula ilişkin görüşleri nelerdir?

4- Okul yöneticilerinin ve öğretmenlerin öğrenen okula ilişkin algıları ve görüşleri arasındaki benzerlikler ve farklıliklar nelerdir?

\section{YÖNTEM}

\section{Araştırma Modeli}

Araştırmada nicel ve nitel yöntemler birlikte kullanılmıştır. Nicel ve nitel araştırma tekniklerinin birlikte kullanılmasında üç desen işe koşulabilir. Bunlar zenginleştirilmiş (triangulation) desen, açıklayıcı (explanatory) desen ve keşfedici (exploratory) desen olarak ele alınabilir. Zenginleștirilmiş desende nicel ve nitel veriler birlikte toplanır, bu verilerin birbirlerini destekleyip desteklemediğine bakılır. Açıklayıcı desende ise önce nicel veriler toplanır, sonra bu verileri yorumlamak için nitel araştırmaya gidilir. Keşfedici desende önce nitel veriler toplanır, sonra bunlara dayanarak nicel verilerin toplanmasına gidilir (Fraenkel ve Wallen, 2006'dan akt. Sönmez ve Ceylanpınar, 2011). Bu bağlamda değ erlendirildiğinde bu araştırma açıklayıcı desen kapsamında yapılandırılmıştır. İki araştırma yönteminin birlikte kullanılmasıyla konu ile ilgili daha kapsamlı ve derinlemesine bilgi edinilmesi, araştırma sonucunda daha güvenilir ve sağlıklı çıkarımlarda bulunulması amaçlanmaktadır.

Nicel Araştırma Modeli: Araştırmanın nicel bölümünde öğretmenlerin ve yöneticilerin bazı değişkenlere göre Öğrenen Okul algılarının incelenmesi amaçlanmaktadır. $\mathrm{Bu}$ çerçevede araştırma, ilişskisel tarama modelinde desenlenmiştir. Karasar (2003)'a göre tarama modelinde araştırmaya konu olan olay, birey ya da nesne, kendi koşulları içinde ve olduğu gibi tanımlanmaya çalışılır. Bu kapsamda araştırmada eğitim kurumlarında görev yapan okul yöneticileri ve öğretmenlerin öğrenen okul algıları var olduğu şekliyle değerlendirilmiştir.

Nitel Araştırma Modeli: Araştırmanın nitel bölümünde durum deseni kullanılmıştır. Nitel durum çalışmasının amacı belirli bir duruma ilişkin sonuçlar ortaya koymak iken en temel özelliği bir ya da birkaç durumun katılımcı gözlemleri, derinlemesine görüşmeler yoluyla doküman toplama ile elde edilen ve analiz edilen verilerin derinliğine ve boylamsal olarak incelenmesini içerir (Yıldırım ve Şimşek, 2011).

\section{Çalışma Grubu}

Nicel Araştırma Yönteminde Kullanılan Çalışma Grubu: Araştırmanın evreni; Sivas- Zara, Hafik, İmranlı ilçelerinde Milli Eğitim Bakanlığı'na bağlı ilköğretim ve ortaöğretim kurumlarında görevli okul yöneticileri ve öğretmenlerinden oluşmaktadır. 2012 Eylül ayı itibari ile söz konusu ilçelerde görev yapan toplam öğretmen ve yönetici sayısı 367'dir. Araştırmada örneklem alınma yoluna gidilmemiştir. Evrene ulaşmak hedeflenmiştir. Ancak katılımın gönüllülük esasına dayanması ve eksik doldurma sebebiyle 2012 Eylül ayında görevde olan 55'i okul yöneticisi ve 281'i öğretmen olmak üzere 336 kişiye ulaşılmıştır. 
Nitel Araştırma Yöntemde Kullanılan Çalışma Grubu: Araştırmanın nitel bölümünde amaçlı örnekleme yöntemlerinden maksimum çeşitlilik örnekleme yöntemi kullanılmıştır. Maksimum çeşitlilik örneklemesi, göreli olarak küçük bir örneklem oluşturarak bu örneklemde çalışılan probleme taraf olabilecek bireylerin çeşitliliğini maksimum derecede yansıtmaktır (Yıldırım ve Şimşek, 2011). Bu bağlamda araştırmada, öğrenen okula taraf olan öğretmenler ve yöneticiler örnekleme alınmıştır. Buna göre örnekleme alınacak katılımcılar belirlenirken branş, görev ve cinsiyet kriterleri dikkate alınmıştır. Tablo 1'de çalışma grubunun özelliklerine yer verilmiştir.

Tablo 1. Çalışma Grubunun Özellikleri

\begin{tabular}{|c|c|c|c|c|c|c|}
\hline Rumuz & Cinsiyet & Branş & Mezun Olduğu Bölüm & Görev & Hizmet Süresi & Görev Yeri \\
\hline$K_{1}$ & Erkek & Sinif & Sınıf Öğretmenliği & $\begin{array}{l}\text { Okul } \\
\text { Yöneticisi }\end{array}$ & 18 & Sivas Merkez \\
\hline $\mathbf{K}_{2}$ & Kadın & Branş & Fen Bilgisi Öğretmenliği & Öğretmen & 7 & Sivas Merkez \\
\hline $\mathbf{K}_{3}$ & Erkek & Sinif & Sınıf Öğretmenliği & Öğretmen & 11 & Sivas Merkez \\
\hline $\mathbf{K}_{4}$ & Erkek & Sinif & Sinıf Öğretmenliği & $\begin{array}{l}\text { Okul } \\
\text { Yöneticisi }\end{array}$ & 16 & Sivas Merkez \\
\hline $\mathbf{K}_{\mathbf{5}}$ & Erkek & Sinif & Sinıf Öğretmenliği & $\begin{array}{l}\text { Okul } \\
\text { Yöneticisi }\end{array}$ & 5 & Sivas Merkez \\
\hline $\mathbf{K}_{6}$ & Kadın & Branş & Fen Bilgisi Öğretmenliği & $\begin{array}{l}\text { Okul } \\
\text { Yöneticisi }\end{array}$ & 8 & Sivas Merkez \\
\hline $\mathbf{K}_{7}$ & Kadın & Branş & Türkçe Öğretmenliği & Öğretmen & 6 & Sivas Merkez \\
\hline $\mathbf{K}_{8}$ & Erkek & Sinif & Fen Fakültesi Kimya Bölümü & Öğretmen & 19 & Sivas Merkez \\
\hline $\mathbf{K}_{9}$ & Erkek & Branş & Sosyal Bilgiler Öğretmenliği & $\begin{array}{l}\text { Okul } \\
\text { Yöneticisi }\end{array}$ & 8 & Sivas Merkez \\
\hline $\mathbf{K}_{10}$ & Kadın & Brans & Matematik Öğretmenliği & Öğretmen & 3 & Sivas Merkez \\
\hline
\end{tabular}

Çalışma grubunu oluşturan katılımcıların dağılımı branş, kıdem, cinsiyet ve görev değişkenleri gözetilerek oluşturulmaya çalışılmıştır. Bu kapsamda çalışma grubunu 1'i kadın 4'ü erkek; 2'si branş öğretmeni, 3'ü sınıf öğretmeni olan ve kıdemleri 8 ile 18 yıl arasında değişen 5 okul yöneticisi ile 3'ü kadın 2'si erkek; 3'ü branş öğretmeni, 2'si sınıf öğretmeni olan ve kıdemleri 3 ile 19 yıl arasında değişen 5 öğretmen oluşturmaktadır.

\section{Veri Toplama Araçları}

Nicel Veri Toplama Aracı: Araştırmanın nicel bölümünde veri toplama aracı olarak öğrenen okul ölçeği kullanılmıştır. Öğrenen Okul Ölçeği araştırmacılar Uğurlu, Doğan ve Yiğit (2014)tarafından geliştirilmiştir. Öğrenen Okul ölçeğinin geliştirilmesi sürecindeörneklem grubu Sivas İli ilköğretim ve ortaöğretim okullarından görev yapan öğretmenler olarak belirlenmiştir. Ölçeğin yapı geçerliği için açıklayıcı ve doğrulayıcı faktör analizi yapılmıştır. Açıklayıcı faktör analizinde 206 öğretmenden, doğrulayıcı faktör analizinde ise 225 öğretmenden elde edilen veriler kullanılmıştır. Güvenirlik çalışmalarında ise, iç tutarlılık katsayısı ve madde analizlerine yer verilmiştir. Verilerin istatistikî işlemlerinde SPSS 18.00 ve LISSREL 8.7 paket programından yararlanılmıştır. Araştırma bulgularına dayalı olarak Öğrenen Okul Ölçeğinin (ÖOÖ) 20 maddeden oluşan 4 faktörlü geçerli ve güvenilir bir ölçek olduğu söylenebilir.

Ölçeğin oluşturulma sürecinde ilgili alan yazından faydalanılarak 31 madde yazılmıştır. Ölçeğin yapı geçerliliğini test etmek için öncelikle açımlayıcı faktör analizi yapılmıştır. Toplanan verilerin açımlayıcı faktör analizine uygunluğunu test etmek için Kaiser-Meyer-Olkin (KMO) katsayısı ve Bartlett Sphericity testleri ile gerekli ön incelemeler gerçekleştirilmiştir. Yapılan analizler sonucunda, KMO değeri .91; Bartlett Sphericity Testi sonucu 2213,103 $(p<0,05)$ olarak bulunmuştur. KMO değerinin .50'nin altına düştügü zaman faktör analizi yapılamayacağı yorumu yapılır. 0,80 ile 0,90 arasındaki değerler "iyi” düzeyde 
kabul edilir. KMO değerinin. 80'den büyük olması ve 150 civarında örneklem büyüklüğünü yeterli sayan görüşlere göre bu çalışmada kullanılan örneklem sayısı olarak 206 sayının yeterli olduğu söylenebilir (Büyüköztürk 2007). Bartlett Sphericity testi sonucu ki-kare değerinin ise $p<0,05$ düzeyinde anlamlı olduğu görülmektedir. Bu sonuçlar veriler üzerinde açımlayıcı faktör analizi yapılabileceğinin göstergesi olarak kabul edilir. Faktör analizinde her bir maddenin faktörlerce açıklanan ortak varyansının, .30'dan düşük olmaması beklenir. Ölçeğin faktör deseni için dik döndürme yöntemlerinden maksimum değişkenlik tekniği seçilmiştir. Bu bağlamda yapılan analiz sonucunda faktör yük değeri . 40'ın altında yer alan 9 madde ve binişik olan 2 madde elenmiştir. Yirmi madde üzerinden yapılan faktör analizinde ortak varyans yük değerlerinin .49 ile .84 arasında değiştiği gözlenmiştir.

İkinci grup öğretmenlerden elde edilen verilerle yapılan doğrulayıcı faktör analizi sonuçlarına göre ölçek, takım halinde öğrenme gizil değişkeni, zihni modeller gizil değişkeni, paylaşılan vizyon gizil değişkeni, kişisel hakimiyet gizil değişkeni olarak dört faktör altında doğrulanmaktadır. Ölçeğin, DFA'da $\chi^{2}$ 'nin serbestlik derecesine oranının beşin altında olması nedeniyle kabul edilir uyum, CFI değerinin .96 olması nedeniyle iyi uyum, RMSEA'nın .07 olması nedeniyle mükemmel uyum, GFI'nın .90 olması nedeniyle iyi uyum, AGFI'nın .87 olması nedeniyle iyi uyum değerlerine sahip olduğu görülmektedir.

Açımlayıcı ve doğrulayıcı faktör analizleri sonucunda Öğrenen Okul ölçeğinin birinci faktörü 8 maddeden oluşmakta ve bu faktörde madde yük değerleri. 492ile. 760aralığındadeğişmektedir. Birinci faktör altında yer alan 8 madde "Takım Halinde Öğrenme" alt boyutu olarak ifade edilmiştir. Ölçeğin ikinci faktörü 5 maddeden oluşmakta ve İkinci faktörde yer alan maddelerin madde yük değerleri .648 ile .840 aralığında değişmektedir. İkinci faktör altında yer alan 5 madde "Zihni Modeller" alt boyutu olarak ifade edilmiştir. Ölçeğin üçüncü faktörü 3 maddeden oluşmakta ve üçüncü faktörde yer alan maddelerin madde yük değerleri. 691ile. 765aralığında değişmektedir. Üçüncü faktör altında yer alan 3 madde "Paylaşılan Vizyon" alt boyutu olarak ifade edilmiştir. Ölçeğin dördüncü faktörü 4 maddeden oluşmakta ve dördüncü faktörde yer alan maddelerin madde yük değerleri. 591 ile .796 aralığında değişmektedir. Dördüncü faktör altında yer alan 4 madde "Kişisel Hâkimiyet" alt boyutu olarak ifade edilmiştir.

Birinci faktör ölçeğin toplam varyansının \%21,46'sını; ikinci faktör \%18.60'ını, üçüncü faktör \%13.18'ini; dördüncü faktör ise, \%10.31'ini açıklamaktadır. Ölçeğin açıkladığ toplam varyans $\% 63.76$ 'dir. Ölçekte yer alan maddelerin korelasyon katsayıları .32 ile .80 arasında değişmektedir. Bu değerler, maddelerin bir bölümünün orta düzeyde (.30 -.70), bir bölümünün ise yüksek (.70-1.00) düzeyde madde toplam korelasyonuna sahip olduğunu göstermektedir (Büyüköztürk, 2007). Ölçeğin güvenirlik değerleri ise Tablo 2'de verilmiştir:

\begin{tabular}{llll}
\hline & Tablo 2. Ölçek ve Alt Boyutlarının Güvenirlik Değerleri & \\
\hline Faktör & Cronbach Alfa & Spearman Brown & GuttmanSplit-Half \\
Takım Halinde Öğrenme & .89 & .88 & 87. \\
Zihni Modeller & .89 & .90 & .86 \\
Paylaşılan Vizyon & .84 & .74 & .73 \\
Kişisel Hakimiyet & .69 & .72 & .69 \\
Toplam & .92 & .86 & .83 \\
\hline
\end{tabular}

Tablo 2'de görüldüğü üzere ölçeğin Cronbach Alfa değerleri .69 ile .92 aralığında; Spearman Brown değerleri .72 ile .90 aralığında; GuttmanSplit-Half değerleri .73 ile .87 aralığında değişmektedir. Bu sonuçlara dayanılarak ölçeğin güvenilir olduğu söylenebilir. 
Ölçekte, Okulumuzdaki öğretmenler "Nasıl daha iyi yaparım?” arayışı içerisindedirler; okulumuzda paylaşılan görevler takım halinde çalışılarak gerçekleştirilir; okulumuzda öğretmenler her konuda yönetimden destek görürler; okulumuzun vizyonu "Yaşam Boyu Öğrenme" temeline dayalıdır; diğer okullardaki meslektaşlarımla tartışarak bilgi alış verişinde bulunurum, gibi maddeler yer almaktadır.

Nitel Veri Toplama Aracı: Araştırma kapsamında katılımcılara yöneltilen açık uçlu sorular öncelikle araştırmanın çalışma grubunda yer almayan iki okul yöneticisine ve iki öğretmene yöneltilmiş, elde edilen sonuçlara göre soruların açık ve anlaşılır olduğu görülmüştür. Ayrıca sorular nitel araştırmalar konusunda uzman bir öğretim üyesi tarafından incelemeye tabi tutulmuş ve son olarak bir Türkçe öğretmeni tarafından gözden geçirilmiştir.

Veri toplama sürecinde katılımcılara açık uçlu sorular yöneltilerek araştırma sürecinde beklenmeyen veya planlanmayan cevapların alınması sağlanmış, böylece konu hakkında daha geniş ve ayrıntılı bilgiye sahip olunmuştur (Büyüköztürk, Çakmak, Akgün ve Demirel 2012:127). Sorular katılımcıların belirli bir anda belirli bir konuya yönelik ne düşündüğünü ya da ne duyduğunu saptamaya yönelik tutum, inanç ve kanı sorularıdır (Balc1, 2001). Araştırmanın soruları hazırlanırken öğrenen okul ölçeğinin alt boyutları dikkate alınmıştır. Buna göre araştırmada katılımcılara yöneltilen sorular şunlardır: $\boldsymbol{i}$. Okul paydaşları, okulun ortak amaçları ve vizyonu kapsamında birlikte hareket edebiliyor mu? (paylaşılan amaç ve vizyon boyutu) ii Okul ortamı kişisel gelişiminize katkı sağlayacak bir yapıda mıdır? (kişisel hâkimiyet boyutu) iii. Okul ortamı birlikte öğrenme faaliyetleri için uygun firsatlar sunmakta mıdır? (takım ile öğrenme boyutu) iiii. Okul paydaşlarının hayata bakış açıları okulun öğrenme ortamını etkilemekte midir? Nasıl? (zihni modeller boyutu).

Araştırma kapsamında elde edilen sorular 10 katılımcıya yöneltilmiştir. Araştırmaya ilişkin veriler Nisan 2013- Haziran 2013 tarihleri arasında belirlenen katılımcılarla yapılan konu odaklı görüşme yöntemiyle toplanmıştır. Konu odaklı görüşmeler kişilerin yaşamlarından ziyade bir program, konu ya da süreç üzerine odaklanmış görüşmelerdir. Görüşmeler hakkında katılımcılara bilgi verilmiş daha sonra katılımcılardan randevu alınmış ve tam randevu saatinde okullara gidilerek sessiz bir ortamda görüşmeler gerçekleştirilmiştir. Görüşmelerde katılımcıların onayı ile ses kayıt cihazı kullanılarak 200 dakikalık ses kaydı elde edilmiştir.

Nitel Araştırmada Geçerlik ve Güvenirlik: Nitel araştırma yaklaşımının benimsendiği bu araştırmada geçerlik ve güvenirlik kavramları yerine inandırıcılık, aktarılabilirlik, tutarlılık ve teyit edilebilirlik kavramlarının kullanılması daha doğru bir yaklaşım olacaktır. Geçerlik ve güvenirlik kavramları nicel araştırmalara özgü kavramlar niteliğinde olup, nitel araştırmaların temel ilkeleri ve temel paradigması ile çelişmektedir (Mills, 2003:78).

$\mathrm{Bu}$ kapsamda araştırmada inandırıcılığı sağlamak içinöncelikle araştırmanın uygulama sürecinde tüm görüşmeler ses kayıt cihazıyla kayıt altına alınmıştır. Araştırmacı, araştırmanın tüm aşamalarında mümkün olduğunca objektif olmaya dikkat etmiştir. Aktarılabilirlik konusunda araştırmacıların okuyuculara, uygulama ve içerikteki benzerliklere karar vermesi için yeterli detayları vermesi gerekmektedir. $\mathrm{Bu}$ nedenle çalışmanın yöntem bölümünde; araştırmanın yapıldığı yer, zaman ve içerik ile ilgili açıklayıcı bir şekilde bilgi verilmiştir. Araştırmanın tutarlılığını artırmak için çalışmada elde edilen bulguların tamamı yorum ve genelleme yapılmadan doğrudan okuyucuya sunulmuştur. Ayrıca araştırma sürecinde elde edilen tüm veriler, araştırmacının kendisi dışında, başka bir araştırmacı tarafından değerlendirip, ayrı ayrı kodlanmış ve tüm kodlamalar arasında genel anlamda görüş birliği sağlanmıştır. İki araştırmacının birbirinden bağımsız olarak kullandıkları kodların tutarlığ "Görüş Birliği" ya da "Görüş Ayrılığı" şeklinde işaretlemeler yapılarak belirlenmiştir. 
Araştırmanın teyit edilebilirliğini sağlamak için, verilerin nasıl toplandığ kaydedildiği ayrıntılı bir şekilde anlatılmıştır.

\section{Verilerin Analizi}

Nicel Verilerin Analizi: Okul yöneticileri ve öğretmenlerin Öğrenen Okulu algılama düzeylerine ilişkin seçeneklere göre kodlanan puan aralığ öğretmenlerinbazı değişkenlere göre öğrenen okul algılarına ilişkin genel bulguları kapsamında aritmetik ortalama, standart sapma, en yüksek puan ve en düşük puan değerleri hesaplanmış olup demografik bilgilerin sunulmasında frekans ve yüzde değerlerine yer verilmiştir. Araştırmada, öğretmen ve yöneticiler birlikte değerlendirmeye alınmış ve analizler öğretmen ve yönetici sayılarının toplamı üzerinden yapılmıştır. Araştırmada $p$ anlamlılık değeri 0.5 olarak alınmıştır.

Öğrenen Okul Ölçeğini (Toplam) ve alt boyutlarını algılama düzeylerine ilişkin aritmetik ortalama, standart sapma ve seçeneklere göre kodlanan puan aralığı (SKPA) değerlerine yer verilmiştir. Elde edilen aritmetik ortalamanın hangi aralığa tekabül ettiğini belirtmek için seçeneklere göre kodlanan puan aralıkları Hiç Katılmıyorum $(1.00-1.79)$, Katılmiyorum (1.80 - 2.59), Kararsızım (2.60 - 3.39), Kat1liyorum (3.40 - 4.19) ve Tamamen Katıliyorum (4.20 - 5.00) şeklinde belirlenmiştir.

Nitel Verilerin Analizi: Araştırma sürecinde katılımcılarla yüz yüze gerçekleştirilen tüm görüşmeler, ses kayıt cihazıyla, katılımcıların onayı alınarak kaydedilmiştir. Araştırma kapsamında 200 dakikalık görüşme yapılmıştır. Görüşmelerden sonra kaydedilen veriler ham veri olarak Microsoft Word yazı işleme programıyla metne dönüştürülmüştür. Veriler kodlanmadan önce iki araştırmacı tarafından verilerin dökümü olan transkriptler satır satır okunmuştur. Görüşme verilerinin yorumlanması sürecinde betimsel analiz, içerik analizi ve sürekli karşılaştırma tekniği kullanılmıştır. İçerik analizi, bir söylemi anlamada ve yorumlamada, öznel etkenlerden kurtularak toplanan verileri açıklayabilecek kavramlara ve ilişkilere ulaşma amacı taşımaktadır (Bilgin, 2006:1; Yıldırım ve Şimşek, 2006). Bu amaçla veriler dört aşamada analiz edilmiştir: (1) verilerin kodlanması, (2) temaların bulunması, (3) kodların ve temaların düzenlenmesi, (4) bulguların tanımlanması ve yorumlanması. İlk aşamada katılımcıların verdiği cevaplardan elde edilen veriler anlamlı bütünler halinde nasıl bölümlere ayrılabileceği, bu anlamlı bütünlere nasıl bir kod verileceği ve bu farklı bölümlerde yer alan verilerin benzer kodlarla düzenlenip düzenlenemeyeceği dikkate alınarak verilerden elde edilen kodlara göre kodlama süreci tamamlanmıştır. Ortaya çıkan kodlardan yola çıkarak verileri, genel düzeyde açıklayabilen ve kodları belirli kategoriler altında toplayabilen temalar bulunmuştur (Yıldırım ve Şimşek; 2006: 228-239). İki araştırmacı tarafindan aynı süreç takip edilmiş ve ortaya iki araştırmacının ortak görüşleri doğrultusunda kodlar ve temalar çıkmıştır. $\mathrm{Bu}$ kodlar ve temalar düzenlenerek elde edilen bulgular tanımlanmış ve yorumlanmıştır. Ayrıca betimsel analizde, görüşülen bireylerin görüşlerini çarpıcı bir şekilde yansıtmak için s1k sık doğrudan alıntılara yer verilmiştir. Katılımcılara (K1, K2, K3......K10) şeklinde rumuzlar verilmiştir.

\section{BULGULAR VE YORUMLAR}

\section{Öğretmen ve Okul Yöneticilerinin Öğrenen Okula Yönelik Algılarına İlişkin Nicel Bulgular}

Araştırmanın nicel bölümde, ilk olarak okul yöneticileri ve öğretmenlerin Öğrenen OkulÖlçeğini (Toplam) ve alt boyutlarını algılama düzeylerine ilişkin aritmetik ortalama, standart sapma ve seçeneklere göre kodlanan puan aralığı (SKPA) değerlerine yer verilmiştir. İkinci olarak okul yöneticileri ve öğretmenlerinbazı değişkenlere göre öğrenen okul algılarına 
ilişkin genel bulgular kapsamında aritmetik ortalama, standart sapma, en yüksek puan ve en düşük puan değerleri hesaplanmıştır.

\begin{tabular}{|c|c|c|c|c|}
\hline & $\mathrm{n}$ & $\bar{X}$ & SS & Düzey \\
\hline Takım Halinde Öğrenme & 336 & 3,86 & 0,68 & Katıliyorum \\
\hline Zihni Modeller & 336 & 3,95 & 0,76 & Katılıyorum \\
\hline Paylaşılan Vizyon & 336 & 3,95 & 0,65 & Katıliyorum \\
\hline Kişisel Hâkimiyet & 336 & 4,26 & 0,52 & Tamamen Katıliyorum \\
\hline Öğrenen Okul (Toplam) & 336 & 4,01 & 0,65 & Kat1liyorum \\
\hline
\end{tabular}

Tablo 3'de Öğrenen Okul ölçeği ve alt boyutları, seçeneklere göre kodlanan puan aralığı (SKPA) dikkate alınarak değerlendirildiğinde, çalışma grubundaki okul yöneticileri ve öğretmenlerin takım halinde öğrenme, zihni modeller ve paylaşılan vizyon boyutlarının 'katılıyorum" düzeyinde, kişisel hakimiyet boyutunun ise " tamamen katıllyorum" düzeyinde olduğu görülmektedir. Ayrıca ölçeğin toplam aritmetik ortalamasının da 'Katılıyorum' düzeyinde yer aldığ 1 tespit edilmiştir.

$\mathrm{Bu}$ dağılımdan, okul yöneticileri ve öğretmenlerin Öğrenen Okul algılarının "Katılıyorum" düzeyinde olmasından dolayı, öğrenen okulun bir kavram olmaktan çok okullarda işlevsel bir yapı olarak bulunduğu sonucuna ulaşılabilir. Aritmetik ortalamalar incelendiğinde ise, kişisel hâkimiyet boyutunun diğer alt boyutlara göre daha yüksek düzeyde algılandığ 1 görülmektedir. Bu noktada, kişisel hâkimiyet boyutunun kişisel beceri ve yeteneklerin kullanımı ve kendini geliştirme olarak açıklandığı düşünüldügüunde okul yöneticisi ve öğretmenlerin kişisel olarak kendi yeteneklerini kullanma noktasında kendilerini yüksek düzeyde algıladıkları ancak diğer üç boyutun daha çok kurumsal yönünün ağır basmasından dolayı bu üç boyutu kişisel hâkimiyet boyutuna göre daha düşük düzeyde algılamış olabilecekleri söylenebilir.

Tablo 4'de okul yöneticileri ve öğretmenlerin bazı değişkenlere göre Öğrenen Okula ilişkin genel algılarına yer verilmiştir. Tabloda en yüksek ve en düşük puanlarla birlikte aritmetik ortalama ve standart sapma değerleri bulunmaktadır.

\begin{tabular}{|c|c|c|c|c|c|}
\hline & $\mathrm{n}$ & En Yüksek puan & En Düsük Puan & $\overline{\mathrm{X}}$ & SS \\
\hline \multicolumn{6}{|l|}{ Görev } \\
\hline Öğretmen & 281 & 100 & 39 & 79,12 & 0,63 \\
\hline Yönetici & 54 & 100 & 50 & 82,42 & 1,43 \\
\hline Toplam & 335 & 100 & 39 & 80,76 & 1,03 \\
\hline \multicolumn{6}{|l|}{ Cinsiyet } \\
\hline Kadin & 160 & 100 & 39 & 79,08 & 0,88 \\
\hline Erkek & 176 & 100 & 46 & 80,15 & 0,76 \\
\hline Toplam & 336 & 100 & 39 & 79,61 & 0,82 \\
\hline \multicolumn{6}{|l|}{ Yaş } \\
\hline $20-29$ & 139 & 100 & 39 & 78,26 & 0,97 \\
\hline $30-39$ & 148 & 100 & 52 & 81,78 & 0,79 \\
\hline 40 ve üzeri & 48 & 100 & 50 & 77,02 & 1,39 \\
\hline Toplam & 336 & 100 & 39 & 79,02 & 1,05 \\
\hline
\end{tabular}




\begin{tabular}{llllll}
\hline Okul Türü & & & & & \\
Okul Öncesi & 14 & 100 & 60 & 88,78 & 3,51 \\
İlköğretim & 208 & 100 & 39 & 79,92 & 0,7 \\
Lise & 114 & 100 & 39 & 78 & 0,99 \\
Toplam & 336 & 100 & 39 & 82,23 & 1,73 \\
Kıdem & & & & \\
1 ile 10 & 237 & 100 & 39 & 79,47 & 0,71 \\
10 ile 20 & 65 & 100 & 50 & 81,43 & 1,23 \\
21 ve üzeri & 34 & 100 & 69 & 77,33 & 1,63 \\
Toplam & 336 & 100 & 39 & 79,41 & 1,19 \\
\hline
\end{tabular}

Tablo 4`e göre okul yöneticileri ve öğretmenlerin öğrenen okul algılarının ortalamaları görev, cinsiyet, yaş okul türü ve kıdem değişkenlerine göre $(\bar{x}=77,02 ; 3,85)$ ile $(\bar{x}=88,78$; $4,43)$ aralığında değişmektedir. Seçeneklere göre kodlanan puan aralı̆̆ına (SKPA) göre yöneticilerin ve öğretmenlerin, ilgili değişkenlerin tümünde, öğrenen okul algıları "katılıyorum" ve "tamamen katılıyorum" düzeyindedir. En yüksek ortalama ( $\bar{x}=88,78 ; 4,43)$ ile okul türü değişkeninin "okul öncesi” bölümünde iken en düşük ortalama $(\bar{x}=77,02 ; 3,85)$ ile yaş değişkeninin "40 ve üzeri” aralığında yer almaktadır. Okul yöneticileri ve öğretmenlerin öğrenen okul algılarının tüm değişkenlerde "katılıyorum" ve "tamamen katılıyorum" düzeyinde olması, okul yöneticileri ve öğretmenlerin ilgili değişkenlerde benzer alg1 puanlarına sahip olduklarını göstermektedir.

\section{Öğretmen ve Okul Yöneticilerinin Öğrenen Okula Yönelik Görüşlerine İlișkin Nitel Bulgular}

Araştırmanın nitel bölümünde öğretmen ve okul yöneticilerinin görüşlerine başvurulmuştur. $\mathrm{Bu}$ kapsam da oluşturulan sorulardan elde edilen görüşler doğrultusunda aOkulun ortak amaçları ve vizyonuna ilişkin görüşler, b- Okul paydaşlarının kişisel gelişimlerine ilişkin görüşler, c-Okul ortamında birlikte öğrenme faaliyetlerine ilişkin görüşler ve d- Okul paydaşlarının hayata bakış açılarının okulun öğrenme ortamına etkilerine ilişkin görüşler olmak üzere 4 tema oluşturulmuş ve konu bu 4 tema altında incelenmiştir.

Öğretmen ve Okul Yöneticilerinin Okulun Ortak Amaçlart ve Vizyonuna İlişkin Görüsşleri: Katılımcıların çoğunluğu (K 2, K 3, K 5, K 6, K 8, K 10) okulun ortak amaçları ve vizyonu doğrultusunda birlikte hareket etmek bir yana okulun amaçlarını ve vizyonunu anlamakta güçlük çektiklerini; K 9, K 4 ve K 1 rumuzlu katılımcılar okul yöneticisi olarak okullarında vizyon ve misyon çalışmaları yaptıklarını öğretmenlerin, öğrencilerin ve velilerin okulun gelişimi noktasında birlikte hareket etmelerini sağlamaya çalıştıklarını; K 7 rumuzlu katılımcı ise okulunda vizyon ve amaç yönelimli bir atmosfer olduğunu ifade etmiştir.

Okullarını geleceğe taşıma noktasında, okul olarak bir vizyon cümlesine dahi sahip olmadiklarını belirten K 2, K 3 ve K 10 rumuzlu katılımcilar bu durumun sadece kendi okulları için değil genel bir sorun olarak bütün eğitim sisteminde var olduğunu dile getirmişlerdir. K 5 rumuzlu katılımcı bu konudaki düşüncelerini ortak amaçmış, vizyonmuş bunlar süslü laflar! daha okulumuzda doğru dürüst bir temizlik sistemi bile kuramadık şeklinde açıklarken K 6 rumuzlu katılımcı vizyon karın doyurmuyor. Okulun gelir gider dengesini să̆larken bile alnımızın damarı çatlıyor söylemini kullanmıştır. K 8 rumuzlu katılımc1 ise ortak amaç ve vizyon oluşturma konusunda yöneticilerin yetersiz olduğuna vurgu yapmıştır. 
Okul yöneticisi olan $\mathrm{K}$ 9, K 4 ve $\mathrm{K} 1$ rumuzlu katılımcılar okullarında vizyon çalışmaları yaptıklarını, okulun ortak amaç birliği içinde hareket etmesi konusunda faaliyetlerde bulunduklarını ifade ederlerken K 9 rumuzlu katılımcı ancak ögretmenlerden ve ögrencilerden yeterli desteğ $i$ alamıyoruz; K 4 rumuzlu katılımc1 okulumuzu geliştirme noktasında yalnız kalıyoruz söylemleriyle vizyon ve ortak amaç konusunda yaşadıkları sıkıntıları dile getirmişlerdir.

Katılımcılar arasında vizyon ve ortak amaç birliği içerisinde hareket etme konusunda en olumlu söylemlerde bulunan K 7 rumuzlu katılımc1 bu düşüncesini okulumuzun vizyon cümlesini ögretmen, öğrenci ve yöneticilerin katılımıyla birlikte oluşturduk. Vizyon cümlesini destekleyen kısa vadeli ortak amaçlar belirledik. Tüm okulu işin içine kattığımız için okulu ortak bir duygu etrafinda birleştirebildik. Okulumuzun hızla değiştĭgini görmek beni mutlu ediyor şeklinde ifade etmiştir.

K 8 rumuzlu katılımcı dişında tüm katılımcıların ortak amaç ve vizyon konusunda sorunlar yaşadıklarını ifade etmişlerdir. Katılımcıların görüşleri doğrultusunda, ortak amaç ve vizyon noktasında en önemli ayrışma öğretmen ve okul yöneticileri arasında olmuştur. K 5 ve $\mathrm{K} 6$ rumuzlu yöneticiler vizyon ve ortak amaç birliğini yaşadıkları sorunların yanında gereksiz ayrıntılar olarak görürken K 9, K 4 ve K 1 rumuzlu yöneticiler bu konuda yaptıkları çalışmaların desteklenmediğini ifade etmişlerdir. K 2 , K 3 ve K 10 rumuzlu öğretmenler okullarında vizyon cümlesinin dahi olmadığını; K 8 rumuzlu öğretmen bu konuda yöneticilerin yetersiz olduğunu belirtirken yalnızca K 7 rumuzlu katılımcı olumlu görüş bildirmiştir.

Öğretmen ve Okul Yöneticilerinin Okul Paydaşlarının Kişisel Gelişimlerine İlişkin Görüssleri: Katılımcıların çoğunluğu (K 2, K 5, K 6, K 9, K 10) okul ortamından çok okul dışında kendi imkânları ile kişisel gelişimlerine katkı sağladıklarını ifade ederlerken K 1, K 2 ve K 4 rumuzlu katılımcılar kişisel gelişimlerine katkı sağlayamadıklarını; $\mathrm{K} 7$ ve $\mathrm{K} 8$ rumuzlu katılımcılar ise kişisel gelişimleri konusunda çaba sarf etmelerine rağmen bu konuda kendilerini yetersiz bulduklarını belirtmişlerdir.

$\mathrm{K}$ 2, K 5, K 6, K 9, K 10 rumuzlu katılımcılar okul ortamının kişisel gelişim açısından gerekli imkânları sunamadığını, okulda eğitim- öğretim faaliyetlerinin kendilerine bu konuda zaman bırakmadığını ifade ederek okul dışında daha çok internet kaynaklı iletişim araçlarını etkin şekilde kullanarak bu açıklarını giderdiklerini belirtmişlerdir. Ayrıca K 2 rumuzlu katılımc1 okul yönetimi okulu öğretmenler ve ögrencilerin kişisel gelişimlerini destekleyecek imkânlara kavuşturma konusunda yetersizdir $\mathrm{K} 9$ rumuzlu katılımc1 ise kariyer sistemi işletilemezse hiç kimse kendini geliştirmek adına kılını bile kıpırdatmaz söylemlerinde bulunarak kişisel gelişime neden katkı sağlanamadığına ilişkin durum değerlendirmesi yapmışlardır.

Kişisel gelişimlerine katkı sağlayamadıklarını ifade eden $K 1$, K 2 ve K 4 rumuzlu katılımcılar bu düşüncelerini okulun ve öğretmenlerin maddi imkânsızlıklar içerisinde olmalarına, MEB'in öğretmen yetiştirme ve hizmet içi eğitim politikalarının yetersizliğine zamanlarının kısıtlı olmasına dayandırmışlardır. Ayrıca K 4 rumuzlu katılımcı uzman unvanı aldım. Ancak bu unvan kişisel gelişimime herhangi bir katkl yapmadı söylemiyle K 9 rumuzlu katılımcının kariyer sistemi hakkındaki düşüncesine destek vermemiştir.

K 7 ve K 8 rumuzlu katılımcılar ise kişisel gelişim konusunda kendi çabalarının olduğunu ancak dışarıdan yeterli desteği alamadıkları için kendilerini yetersiz hissettiklerine vurgu yapmışlardır. K 7 rumuzlu katılımcı okul ortamında olmayınca dışarıda kendimi geliştirecek ortam bulamıyorum söyleminde bulunurken K 8 rumuzlu katılımcı bazen 
internete giriyorum ama masa başında ne kadar kendimi geliştirebilirim ifadeleriyle yaşadıkları sorunları dile getirmişlerdir.

Katılımcıların tamamı okul ortamının kişisel gelişimlerine katkı sağlamadığını ifade etmiştir. Bu temada en önemli ayrışma katılımcıların kıdemlerinde olmuştur. Kıdemleri 3 ile 8 arasında değişen 5 katılımcı kendilerini kişisel gelişim anlamında yeterli gördüklerini ifade ederken kıdemleri 11 ile 19 arasında değişen 4 katılımcı bu konuda kendilerini yeterli bulmadıklarını ve sorun yaşadıklarını belirtmişlerdir. Yalnızca 6 yıllık kıdeme sahip K 7 rumuzlu katılımc 3-8 yıl arasında kıdeme sahip olanların arasında bulunmasına rağmen bu konuda çaba sarf etmesine rağmen kendisini yeterli hissetmediğini dile getirmiştir.

Öğretmen ve Okul Yöneticilerinin Okul Ortamında Birlikte Öğrenme Faaliyetlerine İlişkin Görüşleri: Katılımcıların çoğunluğu (K 1, K 3, K 5, K 8, K 10) okul ortamında resmi toplantılar dışında bir araya gelmediklerini, birlikte öğrenmenin gerçekleşmesi için resmi olmayan organizasyonlara ihtiyaç duyulduğunu bunun ise zaman kısıtlaması nedeniyle mümkün olamadığını bu kapsamda birlikte öğrenme ortamlarının okul içerisinde gerçekleşmediğini ifade ederken $\mathrm{K} 2, \mathrm{~K} 9$ ve $\mathrm{K} 4$ rumuzlu katılımcılar okullarında zaman zaman düzenlenen seminerlerde ve özellikle zümre toplantılarında birlikte öğrenme faaliyetlerinin gerçekleştiğini ancak yeterli olmadığını, K 6 ve K 7 rumuzlu katılımcılar ise ihtiyaç duyulduğunda bir araya gelerek öğrenme ortamları oluşturabildiklerini belirtmişlerdir.

Resmi toplantıların dişında bir araya gelemediklerini belirten $\mathrm{K}$ 1, K 3, K 5, K 8, K 10 rumuzlu katılımcılar, resmi bir atmosfer olduğu için herkesin bir an önce toplantının bitmesi yönünde beklenti içerisinde olduğunu, resmi toplantılarda zorunlu olmadıkça öğretmenlerin görüş belirtmediğini ve isteksiz olduklarını ifade etmişlerdir. $\mathrm{Bu}$ konuda $\mathrm{K} 8$ rumuzlu katılımc resmi toplantılarda sıkılıyoruz, bir görev bilinci ile hareket ettiğimiz için birlikte bir şeyler ögrenme isteği duymuyoruz, K 10 rumuzlu katılımc1 özellikle zümre ögretmenler kurulu faydalı olabilirdi. Ama bu toplantıda kendisini internetten indirilen hazır tutanaklara bıraktı. Zümrenin adı var kendisi yok. K 3 rumuzlu katılımc1 örneğin bir okul gelişim yönetim ekibi var. İçeriğine bakıyorsunuz okulun gelişimi için çok önemli. Okul gelişim yönetim ekibi içerisinde çeşitli alt ekipler oluşturuluyor. Her ekibin belli zamanlarda toplanıp çalışması gerekiyor. Yani birlikte öğrenmek için iyi bir firsat. Ama ne oluyor. Bu ekibin üyeleri hiçbir zaman toplanmiyor. Ekipten birisi belli dönemlerde bir rapor hazırliyor diğerleri okumadan imza atıyor ve rapor dosyaya gidiyor. Maalesef okulda bütün ekipler bu şekilde çalışıyor. İfadelerini kullanarak yaşanan soruna vurgu yapmışlardır.

K 2, K 9 ve K 4 rumuzlu katılımcılar zaman zaman okulda düzenlenen seminer ve resmi olmayan toplantıların birlikte öğrenme ortamları oluşturulmasını sağladığını, okulda en çok öğrenmenin gerçekleştiği yerin ise ciddiye alınarak yapılan zümre öğretmenler toplantılarının olduğunu ifade etmişlerdir. Bu konuda $\mathrm{K} 2$ rumuzlu katılımcı okulda en çok paylaşım gerçekleştirdiğim ve kendimi bir ekibin parçası gibi hissettiğim yer zümre ögretmenler toplantısıdır, K 9 rumuzlu katılımc1 ise muhtemelen yönetici olmasına bağ 11 olarak okulda sık sık seminer ve hizmet içi eğitim faaliyetleri kapsamında bir araya gelerek ögrenme ortamları oluşturuyoruz. Ama yeterli mi hayır, söylemlerinde bulunmuşlardır.

İhtiyaç duyulduğunda bir araya gelerek öğrenme ortamları oluşturabildiklerini belirten $\mathrm{K} 6$ ve $\mathrm{K} 7$ rumuzlu katılımcılar ise bu durumu okul yöneticilerinin öğretmenlerin alınan kararlara katılımının sağlanmasına ve öğretmenlerle birlikte hareket etmelerine bağlamışlardır. K 6 rumuzlu katılımcı bu konuda baklyorum bazı müdürler okulun tek sahibiymiş gibi davranıyor. Hiç kimseye danışmadan kararlar alıyorlar ve uyguluyorlar. Ögretmenler tabi ki bu durumun farkına varıyor ve kendilerini değersiz hissediyorlar. Okul yönetimi ögretmenlerine değer vermezse onlarla birlikte öğrenme faaliyetleri düzenleyemez. 
Zaten düzenlemek istese de inandırıcı olmaz ifadelerini kullanırken K 7 rumuzlu katılımc1 ögrenen bir okul için lider yöneticilere ihtiyaç olduğuna vurgu yapmıştır.

Katılımcılar okulda birlikte öğrenme ortamlarının oluşmadığ 1 ya da verimli olmadığ 1 konusunda ortak görüş bildirmişlerdir. $\mathrm{Bu}$ temada en önemli ayrışma katılımcıların cinsiyetleri olmuştur. K 1, K 3, K 5, K 8, K 10 rumuzlu katılımcıların tümü erkek olup okulda birlikte öğrenme faaliyetlerinin gerçekleşmediğini belirtirken yine K 4 rumuzlu erkek katılımcı birlikte öğrenme faaliyetlerinin zaman zaman düzenlendiğini ifade etmiştir. Bayan katılımcılar bu konuda erkek katılımcılara göre biraz daha iyimser bir tablo çizmişlerdir. K 4 ve K 9 rumuzlu bayan katılımcılar birlikte öğrenme faaliyetlerinin zaman zaman düzenlendiğini dile getirirken K 6 ve K 7 rumuzlu bayan katılımcılar ihtiyaç duyulduğunda okulda birlikte öğrenme ortamlarının oluşturulduğuna vurgu yapmışlardır.

Ö̆̆retmen ve Okul Yöneticilerinin, Okul Paydaşlarının Hayata Bakış Açılarının Okulun Öğrenme Ortamına Etkilerine İlişkin Görüsşleri: Katılımcıların tamamı okul paydaşlarının hayata bakış açılarının okulun öğrenme ortamını etkilediği konusunda görüş birliğine varmışlardır. Okul ortamına yansıtılan kişisel algıların ve dünya görüşlerinin eğitim ortamına olumlu ve olumsuz etkileri olduğunu belirten katılımcılar olumsuzlukların yaşanmaması için en önemli kriterin demokratik bir okul ortamı ve adil bir yönetim olduğuna vurgu yapmışlardır.

Katılımcılar eğitim çalışanlarının ideolojik ve siyasi görüşlerinin olmasının doğal karşılanması gerektiğini belirterek, adil ve demokratik bir okul ortamında bu farklılıkların zenginlik olarak algılanması gerektiğini ifade etmişlerdir. Bu konuda $\mathrm{K} 3$ rumuzlu katılımcı herkesin dünya görüşü ayrıdır. Benim özgürlüklerime dokunulmadı̆̆ sürece herkese saygl gösterebilirim, K 5 rumuzlu katılımcı demokrasiyi içine sindirmiş insanların her yerde barış ve esenlik içerisinde yaşayabileceğine inanıyorum, K 9 rumuzlu katılımc1 farklı dünya görüşünden olan arkadaşlarımdan çok fazla şey öğreniyorum, K 10 rumuzlu katılımcı ise ögrenmenin ilk şartı farklılıklara saygıdır, söylemlerinde bulunmuşlardır.

Katılımcılar, farklılıklara saygı gösterilmez ise özellikle eğitim kurumlarında büyük sorunların ortaya çıkabileceğini belirtmişlerdir. Bu konuda $\mathrm{K} 1$ rumuzlu katılımcı düşünsenize okul yöneticisi siyasi görüşüne göre ögretmenlerini sinıflandırmış. Böyle bir ortamda ögrenme meydana gelebilir mi?, K 7 rumuzlu katılımc1 benim dünya görüşüme göre davranılıyorsa bırakın ögrenmeyi orada çatışma yaşanması kaçınılmaz hale gelir, $\mathrm{K} 8$ rumuzlu katılımcı okulda hayata bakış açıma göre değil yaptığım çalışmalara bakılarak değerlendirilmek isterim. Bu yapılmıyorsa okulda verimli ögrenme ortamının oluşması mümkün olmaz, söylemlerinde bulunmuşlardır.

$\mathrm{Bu}$ tema içerisinde katılımcıların demografik özelliklerine göre bir farklılaşma oluşmamıştır. Tüm katılımcılar, kişilerin hayata bakış açılarının ve dünya görüşlerinin eğitim ortamına olumlu ve olumsuz yansımaları olabileceği konusunda ortak görüş bildirmişlerdir.

\section{SONUÇ, TARTIŞMA VE ÖNERILLER}

Araştırmada, okul yöneticileri ve öğretmenlerin Öğrenen Okul ölçeğine ve alt boyutlarına ilişkin algıları, seçeneklere göre kodlanan puan aralığ 1 (SKPA), dikkate alınarak değerlendirildiğinde, çalışma grubundaki okul yöneticileri ve öğretmenlerin takım halinde öğrenme, zihni modeller ve paylaşılan vizyon boyutlarının 'Katılıyorum” düzeyinde, Kişisel Hakimiyet boyutunun ise " Tamamen Katıliyorum" düzeyinde olduğu görülmektedir. Ayrıca ölçeğin toplam aritmetik ortalamasının da 'Katılıyorum' düzeyinde yer aldığı tespit edilmiştir. $\mathrm{Bu}$ dağılımdan okul yöneticileri ve öğretmenlerin Öğrenen Okul algılarının "Katılıyorum" düzeyinde olduğu ve öğrenen okulun bir kavram olmaktan çok okullarda işlevsel bir yapı olarak bulunduğu sonucuna ulaşılabilir. Öğrenen örgüt ve öğrenen organizasyon kapsamında 
yapılan çalışmaların sonucunda Bal (2011) okul yöneticisi ve öğretmenlerin okullarına ilişkin öğrenen örgüt algılarının yüksek olduğunu; Şanal (2009) Beden Eğitimi ve Spor Yüksekokullarında görevli akademik personelin çağın yönetim yaklaşımı olarak adlandırılan öğrenen organizasyona doğru bir değişim gösterdiğini; Jokıć ve ark.(2012) Senge'nin beş disiplinine bireysel öğrenme ve örgütsel öğrenme boyutları da eklenerek oluşturulan 7 boyutlu öğrenen örgüt (LO) anketinin 224 öğretmen üzerinde uygulanması sonucu katılımcıların öğrenen örgütü oluşturan özellikler konusunda genellikle olumlu tutum sergilediklerini ifade etmişlerdir. Bal (2011), Şanal (2009) ve Jokıć ve ark. (2012)'nin araştırma sonuçları bu araştırma sonuçlarını desteklemektedir. Ancak Alp (2007)'in ilköğretim öğretmenlerinin öğrenen örgüt disiplininden Kişisel Yeterlilik Bilişsel modeller, Takım Halinde Öğrenme, disiplinlerine ilişkin alg1 düzeylerinin düşük, Sistem Düşüncesi ve Ortak Vizyon disiplinlerine ilişkin alg1 düzeylerinin orta düzeyde olduğu; Boztepe (2007)'nin okul yönetimlerinin öğrenmeyi destekledikleri fikrine katılımcıların kısmen katıldığı; Özus (2005)'un Mesleki ve Teknik Orta Öğretim kurumlarının Öğrenen Organizasyon konumuna gelemedikleri yönetici ve öğretmenlerin kendilerini geliştirerek öğrenmeyi bitmeyen bir süreç olarak görmedikleri, bulguları bu araştırma sonuçlarıyla örtüşmemektedir.

Araştırmanın nitel bulguları ise Alp (2007), Boztepe (2007) ve Özus(2005)'ün araştırma sonuçlarını destekler niteliktedir. Katılımcıların çoğunluğu, okulun ortak amaçları ve vizyonu doğrultusunda birlikte hareket etmek bir yana okulun amaçlarını ve vizyonunu anlamakta güçlük çektiklerini ( $\mathrm{K} 2, \mathrm{~K} 3, \mathrm{~K} 5, \mathrm{~K} 6, \mathrm{~K} 8, \mathrm{~K} 10)$; okul ortamindan çok okul dışında kendi imkânları ile kişisel gelişimlerine katkı sağlayabildiklerini (K 2, K 5, K 6, K 9, $\mathrm{K} 10$ ); okul ortamında resmi toplantılar dışında bir araya gelemediklerini, birlikte öğrenmenin gerçekleşmesi için resmi olmayan organizasyonlara ihtiyaç duyulduğunu bunun ise zaman kısıtlaması nedeniyle mümkün olamadığını bu kapsamda birlikte öğrenme ortamlarının okul içerisinde gerçekleşmediğini (K 1, K 3, K 5, K 8, K 10) ifade ederek okullarında öğrenen okul kavramının işlevsel olmaktan çok durağan bir yapıda var olduğunu betimlemişlerdir. Ancak zihni modeller boyutunda katılımcıların tamamının okul paydaşlarının hayata bakış açılarının okulun öğrenme ortamını etkilediği konusunda görüş birliğine varmış olmaları araştırmanın nicel bulgularıyla paralellik göstermektedir.

Okul yöneticileri ve öğretmenlerin öğrenen okul algılarının ortalamaları görev, cinsiyet, yaş okul türü ve kıdem değişkenlerine göre $(\bar{x}=77,02 ; 3,85)$ ile $(\bar{x}=88,78 ; 4,43)$ aralığında değişmektedir. Seçeneklere göre kodlanan puan aralığına (SKPA) göre yöneticilerin ve öğretmenlerin, ilgili değişkenlerin tümünde, öğrenen okul algıları "katılıyorum" ve "tamamen katıllyorum" düzeyindedir. Okul yöneticileri ve öğretmenlerin öğrenen okul algılarının tüm değişkenlerde "katılıyorum" ve "tamamen katılıyorum" düzeyinde olması, okul yöneticileri ve öğretmenlerin ilgili değişkenlerde benzer alg1 puanlarına sahip olduklarını göstermektedir. İlgili literatürde yer alan, Uysal (2005), Yıldız (2011), Bal (2011), Güleş (2007), Kılıç (2009), Keskin (2007), Alp (2007) ve Banoğlu (2009)tarafından yapılan araştırma sonuçları ile bu araştırma sonuçlarının kısmen örtüştüğü görülmektedir. Söz konusu araştırmaların öğrenen örgüt ve öğrenen organizasyon disiplini çerçevesinde yapılandırılmış olması dikkat çekicidir. Daha çok işletme, kamu yönetimi gibi alanlarda kullanılan öğrenen örgüt ve öğrenen organizasyon kavramlarının eğitim kurumları bünyesinde dönüştürülerek öğrenen okul kavramına ve bu kavramla ilgili oluşturulacak alan yazına ihtiyaç duyulmaktadır. Bu araştırma kapsamında bu ihtiyacın giderilmesi ve alan yazına katkı sağlamak adına öğrenen okul kavramından yola çıkılmıştır. Çünkü işletme ve kamu yönetimi alanlarından farklı olarak kendine özel bir yapılanmaya sahip olan eğitim kurumlarının öğrenen örgüt ve öğrenen organizasyon kavramları içerisinde değerlendirilmesi eğitim kurumlarının sahip olduğu özel yapılanmanın ortaya çıkmasını engellemekte, okullar bir şirket ya da fabrika gibi algılanmaktadır. Eğitim kurumlarının kendi iç dinamiklerinin 
harekete geçirilmesi ve eğitim kurumlarında öğrenme kültürüne daha çok sahip çıkılabilmesi için eğitim kurumlarında öğrenen örgüt ya da öğrenen organizasyon kavramları yerine öğrenen okul kavramı kullanılmalıdır. Bu noktadan hareketle öğrenen okul kavramının yaygınlaştırılmasının eğitim politikaları ve stratejileri için önemli bir gereklilik olduğu söylenebilir.

Araştırmanın nitel bölümünde kıdem, cinsiyet ve görev değişkenlerine göre elde edilen nitel bulgular nicel bulguları kısmen desteklemektedir. Nicel bölümde kıdem, cinsiyet ve görev değişkenlerine göre katılımcıların öğrenen okulu algılama durumları "katılıyorum" ve "tamamen katılıyorum" iken söz konusu değişkenlerde nitel bulgular kısmen farklılıklar göstermektedir.

Katılımcıların tamamı, okul ortamının kişisel gelişimlerine katkı sağlamadığını ifade etmiştir. Bu temada en önemli ayrışma katılımcıların kıdemlerinde olmuştur. Kıdemleri 3 ile 8 arasında değişen 5 katılımcı kendilerini kişisel gelişim anlamında yeterli gördüklerini ifade ederken kıdemleri 11 ile 19 arasında değişen 4 katılımcı bu konuda kendilerini yeterli bulmadıklarını ve sorun yaşadıklarını belirtmişlerdir. Yalnızca 6 yıllık kıdeme sahip K 7 rumuzlu katılımcı 3-8 yıl arasında kıdeme sahip olanların arasında bulunmasına rağmen bu konuda çaba sarf etmesine rağmen kendisini yeterli hissetmediğini dile getirmiştir."Okul paydaşlarının kişisel gelişimlerine ilişkin görüşler” teması içerisinde kıdem değişkeninde ortaya çıkan bu farklılık araştırmanın nicel bulgularını kısmen desteklemektedir.

Katılımcılar, okulda birlikte öğrenme ortamlarının oluşmadığı ya da verimli olmadı̆̆ 1 konusunda ortak görüş bildirmişlerdir. Bu temada en önemli ayrışma katılımcıların cinsiyetlerinde olmuştur. $\mathrm{K} 1, \mathrm{~K} 3, \mathrm{~K} 5, \mathrm{~K} 8, \mathrm{~K} 10$ rumuzlu katılımcıların tümü erkek olup okulda birlikte öğrenme faaliyetlerinin gerçekleşmediğini belirtirken yine $\mathrm{K} 4$ rumuzlu erkek katılımcı birlikte öğrenme faaliyetlerinin zaman zaman düzenlendiğini ifade etmiştir. Bayan katılımcılar bu konuda erkek katılımcılara göre biraz daha iyimser bir tablo çizmişlerdir. K 4 ve K 9 rumuzlu bayan katılımcılar birlikte öğrenme faaliyetlerinin zaman zaman düzenlendiğini dile getirirken K 6 ve K 7 rumuzlu bayan katılımcılar ihtiyaç duyulduğunda okulda birlikte öğrenme ortamlarının oluşturulduğuna vurgu yapmışlardır. "Okul ortamında birlikte öğrenme faaliyetlerine ilişkin görüşler" teması içerisinde, cinsiyet değişkeninde ortaya çıkan bu farklılık araştırmanın nicel bulgularını kısmen desteklemektedir.

Araştırmada K 8 rumuzlu katılımcı dışında tüm katılımcıların ortak amaç ve vizyon konusunda sorunlar yaşadıklarını ifade etmişlerdir. Katılımcıların görüşleri doğrultusunda, ortak amaç ve vizyon noktasında en önemli ayrışma öğretmen ve okul yöneticileri arasında olmuştur. K 5 ve K 6 rumuzlu yöneticiler vizyon ve ortak amaç birliğini yaşadıkları sorunların yanında gereksiz ayrıntılar olarak görürken K 9, K 4 ve K 1 rumuzlu yöneticiler bu konuda yaptıkları çalışmaların desteklenmediğini ifade etmişlerdir. K 2, K 3 ve K 10 rumuzlu öğretmenler okullarında vizyon cümlesinin dahi olmadığını; K 8 rumuzlu öğretmen bu konuda yöneticilerin yetersiz olduğunu belirtirken yalnızca K 7 rumuzlu katılımcı olumlu görüş bildirmiştir. "Okulun ortak amaçları ve vizyonuna ilişkin görüşler" teması içerisinde, görev değişkeninde ortaya çıkan bu farklılık araştırmanın nicel bulgularını kısmen desteklemektedir.

Araştırma bulgularının, öğrenen okula ilişkin sağlıklı bir yapılanmanın gerçekleşmediğine yönelik bir eğilim gösterdiği söylenebilir. Özellikle nitel bulgular bu yönde olup nicel bulgularla çelişmektedir. Bu sonuçlara dayanılarak okullarda öğrenen okulun işleyişine ilişkin olarak sağlıklı bir yönetim sürecine ihtiyaç olduğu ifade edilebilir. Bu bağlamda bireylere göre öğrenme yöntemlerinin farklılaşması nedeniyle öğrenen okullara duyulan ihtiyacın arttığını dile getiren Middlewood, Parker ve Beere, (2005)'i destekler nitelikte Schechter ve Qadach, (2012) araştırmalarının sonucunda örgütsel öğrenme 
mekanizmasının (OLM), okulun dinamik yapısı ile öğretmenlerin tutumları arasında bağ kurduğunu ifade etmiş, Higgins, Ishimaru, Holcombe ve Fowler (2011) ise 941 öğretmen üzerinde yapılan araştırma sonuçlarına göre öğrenen okulun yapılandırılmasında öğretmenlerin, sağlıklı bir psikolojik ortamın, deneyimlerin ve güçlendirici liderliğin yüksek seviyelerde olması gerektiği söylemine vurgu yapmıştır.

Araştırmadan elde edilen bulgulara dayanılarak:

Okul yöneticileri ve öğretmenlerin Öğrenen Okul algılarının geliştirilmesi için birbirlerinden öğrenebilecekleri eğitim ortamları düzenlenmeli, onların sürekli öğrenme ihtiyacı hissetmelerini sağlayacak çalıştaylar yapılmalı, öğretmen yetiştiren kurumlar programlarında öğretmenlere sürekli öğrenme, kendini geliştirme kültürü kazandırabilecek etkinlik ve derslere yer vermeli ve son olarak okul yöneticilerine liderlik eğitimleri verilerek okulların vizyon kazanmalarının önünün açılması sağlanmalıdır.

\section{KAYNAKÇA}

Akat, İ. ve Budak, G. (2002). İşletme yönetimi. İzmir: Barış Yayınları.

Akhtar, N.\&Khan, R.A. (2011). Exploring the paradox of organizational learning and learning organization. Interisciplinary Journal of Contemporary Research in Business, 2(9), 257-270.

Akkoç, H. (2008). Öğrenen örgüt oluşumunda bilgi yönetimi uygulamalarının rolü: Afyon Kocatepe Üniversitesi İktisadi İdari Bilimler Fakültesi uygulamast. (Yüksek lisans tezi, Kocatepe Üniversitesi, Sosyal Bilimler Enstitüsü, Afyon). http://tez2.yok.gov.tr/ adresinden edinilmiştir.

Alipour, F. \& Karimi, R. (2011). Mediation role of innovation and knowledge transfer in there lationship between learning organization and organizational performance. International Journal of Business and Social Science, 2(19), 144-147.

Alp, A. (2007). Illköğretim öğretmenlerinin ögrrenen örgüt kültürüne ilişkin algıları.(Yüksek lisans tezi, Beykent Üniversitesi, Sosyal Bilimler Enstitüsü, İstanbul). http://tez2.yok.gov.tr/ adresinden edinilmiştir.

Atak, M. (2009). Öğrenen örgüt ve örgütsel bă̆lllık ilişkisi. (Doktora tezi, Atatürk Üniversitesi Sosyal Bilimler Enstitüsü, Erzurum). http://tez2.yok.gov.tr/ adresinden edinilmiştir.

Aybar, S. (2011). İşletmelerde öğrenen örgütler ve iş verimliliği ilişkisinin analizi: otel işletmelerinde bir uygulama. (Yüksek lisans tezi, İstanbul Ticaret Üniversitesi Sosyal Bilimler Enstitüsü, İstanbul). http://tez2.yok.gov.tr/ adresinden edinilmiştir.

Bakan, İ. (2011). Çağdaş yönetim yaklaşımları ilkeler, kavramlar ve yaklaşımlar. İstanbul: Beta Yayın Dağıtım.

Bal, Ö. (2011). İlköğretim okullarında görev yapan okul yöneticisi ve ögretmenlerin öğrenen örgüt olarak okullarına ilişkin algıları (Başakşehir örneği). (Yüksek lisans tezi, Yıldız Teknik Üniversitesi, Sosyal Bilimler Enstitüsü). http://tez2.yok.gov.tr/ adresinden edinilmiştir.

Balc1, A. (2001). Sosyal bilimlerde araştırma (yöntem, teknik ve ilkeler). (3. Bask1). Ankara: Pegem A Yayincilik. 
Banoğlu, K. (2009). İlköğretim okullarında görev yapmakta olan yönetici ve ögretmenlerin ögrenen örgüt algisı. (Yüksek lisans tezi, Yıldız Teknik Üniversitesi, Sosyal Bilimler Enstitüsü, İstanbul). http://tez2.yok.gov.tr/ adresinden edinilmiştir.

Bejinaru, R. \& Lordache, S. (2011, April). Intellectual capital Dynamics with in the learning organization. The 3rd European Conference on Intellectual Capitalheld at University of Nicosia, Cyprus.

Bilgin, N. (2006). Sosyal bilimlerde içerik analizi. (2. Bask1). Ankara: Siyasal Yayıncılık.

Boztepe, C. (2007). Mesleki ve teknik eğitimin öğrenen okul boyutunun analizi, (Yüksek lisans tezi, Dumlupınar Üniversitesi, Sosyal Bilimler Enstitüsü, Kütahya). http://tez2.yok.gov.tr/ adresinden edinilmiştir.

Braham, J. B. ( 1998). Öğrenen bir organizasyon yaratmak. Çev: Ali Tekcan. İstanbul: Rota Yayınları.

Büyüköztürk, Ş. (2007). Sosyal bilimler için veri analizi. Ankara: Pegem A Yayıncılık.

Büyüköztürk, Ş., Çakmak, E.K., Akgün, K.Ş. ve Demirel, F. (2012). Bilimsel araştırma yöntemleri. (12. Basım). Ankara: Pegem A Yayıncılık.

Çetinel, M.H. (2011). Insan kaynaklarl yönetiminde eğitim fonksiyonunun öğrenen örgüt oluşumuna etkilerine ilişkin bir araştırma (Yüksek Lisans Tezi, Kocatepe Üniversitesi, Sosyal Bilimler Enstitüsü, Afyon). http://tez2.yok.gov.tr/ adresinden edinilmiştir.

Çoban, G. (2006). Öğrenen organizasyon ve bankacılık sektöründeki uygulaması. (Yüksek lisans tezi, Selçuk Üniversitesi, Sosyal Bilimler Enstitüsü, Konya). http://tez2.yok.gov.tr/ adresinden edinilmiştir.

Efil, İ. (2002). İşletmelerde yönetim ve organizasyon. İstanbul: Alfa Yayınevi.

Eğmir, E. (2012). Okul yöneticilerinin koçluk özelliklerinin okulun öğrenen organizasyon olmasindaki etkililik düzeyi. (Yüksek lisans tezi, Kocatepe Üniversitesi Sosyal Bilimler Enstitüsü, Afyon). http://tez2.yok.gov.tr/ adresinden edinilmiştir.

Eren, E. (2010). Örgütsel davranış ve yönetim psikolojisi. İstanbul: Beta Yayınları.

Ergani, B. (2006). Öğrenen bir örgüt olarak üniversiteler: Dumlupınar üniversitesi Kütahya meslek yüksekokulu örneği. (Yüksek lisans tezi, Dumlupınar Üniversitesi, Sosyal Bilimler Enstitüsü, Kütahya). http://tez2.yok.gov.tr/ adresinden edinilmiştir.

Ferraria, C.C.M.G. \& Pulecio, D.L.G. (2012). A case study of inhibitors for information flow in global product portfolio management. Department of Technology Management and Economics Division of Innovation Engineering and Management Chalmers University of Technology Göteborg, Sweden. Report No. E 2012:062

Forozandeh, L., Soleimani, M. Nazari, A. S. \& Nasri, H. (2011). Studying the relationship between components of the learning organization and organizational commitment. Interdisciplinary Journal of Contemporary Research in Business, 3(6), 497-509.

Güleş, H. (2007). İstanbul ili Bayrampaşa ilçesindeki resmi ilköğretim okulu yönetici ve ögretmenlerin öğrenen organizasyona ilişkin alglları. (Yüksek lisans tezi. Yeditepe Üniversitesi, Sosyal Bilimler Enstitüsü, İstanbul). http://tez2.yok.gov.tr/ adresinden edinilmiştir.

Hawamdeh, B. \& Jaradat, M.H. (2012). Basics of the "learning organization' at jordanian schools : A Case Study. Education, 132(3), 689-696. 
Higgins, M., Ishimaru, A., Holcombe, R. \& Fowler, A. (2011). Examining organizational learning in schools: the role of psychological safety, experimentation, and leadership that reinforces learning. Education Change. 13, 67-94p.

Wayne K.H. \& Cecil K. M. (2010). Egitim yönetimi teori. Araştırma ve uygulama. (Çev. Selahattin Turan). Ankara: Nobel Kitabevi.

Jillinda, J., Kidwell Karen M., Vander, L. \& Sandra, L. J. (2000). Knowledge management practices applying corporate in higher education. Educause Quarterly, 23(4),28-33.

Jokıć, S., Ćosıc, L., Sajfert, Z., Pečujlija, M. \& Pardanjac, M. (2012). Schools as learning organizations: Empirical Study In Serbia. Metalurgıa Internatıonal, 17(2), 83-89.

Karasar, N. (2003). Bilimsel araştırma. Ankara: Nobel Yayıncılık.

Kerman, B., Freundlich, M., Lee, M.J. \& Brenner, E. (2012). Learning whiledoing in the human services: Becoming A Learning Organization Through Organizational Change. Administration In Social Work, 36, 234-257.

Keskin, M.B. (2007). Öğrenen organizasyon olma sürecinde ilköğretim okulu yönetici ve ögretmenlerinin vizyon geliştirme düzeyleri.(Yüksek lisans tezi. Yeditepe Üniversitesi, Sosyal Bilimler Enstitüsü, İstanbul). http://tez2.yok.gov.tr/ adresinden edinilmiştir.

Kılıç, F. (2009). Ortaöğretim kurumlarında görev yapan yönetici ve ögretmenlerin ögrenen örgüte ilişkin algl düzeyler (Bolu ili örneği). (Yüksek lisans tezi, Eskişehir Üniversitesi, Sosyal Bilimleri Enstitüsü, Eskişehir). http://tez2.yok.gov.tr/ adresinden edinilmiştir.

Koçel, T. (2001). Işsletme yöneticiliği- yönetim ve organizasyon. İstanbul: Beta Basım.

Koçel, T. (2005). İşletme Yöneticiliği: yönetim organizasyon, organizasyonlarda davranış, klasik- modern- çağdaş ve güncel yaklaşımlar. İstanbul: Beta Basım.

Lyle, E.R. (2012). Learning organisation [Al] learning. International Journal of Business and Social Science, 3(6), 217-221.

Middlewood, D., Parker, R. \& Beere, J. (2005). Creating a learning school. London: A Sage Publications Company.

Mills, G. E. (2003). Action research a guide for the teacher researcher (2 nd. edition). Boston: Pearson Education.

Mohanty, K. \& Kar, S. (2012). Achieving innovation and success: Organizational learning. SCMS Journal of Indian Management, January - March.

Özus, E. (2005). M.E.B. e bağlı Konya ilindeki mesleki ve teknik orta öğretim kurumlarında çalışan yönetici ve öğretmenlerin öğrenen organizasyonu algılamaları. (Yüksek lisans tezi, Selçuk Üniversitesi, Sosyal Bilimler Enstitüsü, Konya). http://tez2.yok.gov.tr/ adresinden edinilmiştir.

Pekel, H. (2007). Öğrenen organizasyonlar ve örgüt kültürü arasındaki etkileşim. (Yüksek lisans tezi, Anadolu Üniversitesi, Sosyal Bilimler Enstitüsü. Eskişehir). http://tez2.yok.gov.tr/ adresinden edinilmiştir.

Schechter, C. \& Qadach, M. (2012). Toward an organizational model of change in elementary schools: the contribution of organizational learning mechanisms. Educational Administration Quarterly, 48(1), 116- 153.

Senge, P. M. (1990). “The leader's New Work: building learning organizations". Sloan Management Review, 32(1), 7-23. 
Sönmez, V. ve Alacapınar, G. F. (2011). Örneklendirilmiş Bilimsel araştırma yöntemleri. Ankara: Anı yayıncılik.

Srihawong, J. \& Srisa-Ard, B. (2012). Development of the learning organization model: a case of sisaketrajabhat university. European Journal of Social Sciences. 27(2), 233241 .

Subaş, A. (2010), Illkögrretim okullarında çalışan sınıf ve branş öğretmenlerinin öğrenen örgütü (okulu) algılamaları. (Yüksek lisans tezi, Marmara Üniversitesi, Eğitim Bilimleri Enstitüsü, İstanbul). http://tez2.yok.gov.tr/ adresinden edinilmiştir.

Şahinkesen, Ö.G. (2010). Öğrenen organizasyonlar Gaziosmanpaşa Üniversitesi'nde bir uygulama. (Yüksek Lisans Tezi, Gaziosmanpaşa Üniversitesi, Sosyal Bilimler Enstitüsü, Tokat). http://tez2.yok.gov.tr/ adresinden edinilmiştir.

Şanal, E.E. (2009). Beden eğitimi ve spor yüksekokullarında görevli akademik personelin ögrenen örgüt kültürüne ilişkin görüşleri. (Yüksek lisans tezi, Muğla Üniversitesi, Sosyal Bilimleri Enstitüsü, Muğla). http://tez2.yok.gov.tr/ adresinden edinilmiştir.

Şimşek, M.Ş. ve Kıngır, S. (2006). Çăgdaş yönetim araçlarından seçmeler. Ankara: Nobel Yayın Dağıtım.

Şimşek, Y. ve Yıldırım, C.M. (2004). Öğrenen okulların kültürel yapıları. XIII. Ulusal Eğitim Bilimleri Kurultayı, İnönü Üniversitesi, Eğitim Fakültesi, Malatya.

Tee, N. P. (2004). The learning organisation and the innovative organisation. Human Systems Management, 23, 93-100.

Töremen, F. (2011). Öğrenen okul. Ankara: Nobel Yayınevi.

Turan, S. (2011). Üniversite yapısı içerisinde öğrenen örgüt ve örgütsel bağlılık ilişkisi üzerine bir araştırma. Kuram ve Uygulamada Eğitim Yönetimi Dergisi, 17(4), 627-638.

Uğurlu, C.T., Doğan, S. ve Yiğit, Y. (2014). Öğrenen okul ölçeği geçerlik ve güvenirlik çalışması. Türk Eğitim Bilimleri Dergisi, 12 (1), 35-45.

Uysal, A. (2005). Okul Öncesi eğitim kurumlarında görev yapan yönetici ve ögretmenlerin ögrenen organizasyona ilişkin algıları. (Yüksek lisans tezi, Selçuk Üniversitesi, Sosyal Bilimler Enstitüsü, Konya). http://tez2.yok.gov.tr/ adresinden edinilmiştir.

Yıldırım, A. ve Şimşek, H. (2011). Sosyal bilimlerde nitel araştırma yöntemleri. (8. Baskı). Ankara: Seçkin Yayıncılık.

Yıldız, H. (2011). Kamu ve özel ilköğretim kurumlarında çalışan öğretmenlerin öğrenen örgüte ilişkin algıları. (Yüksek lisans tezi. Balıkesir Üniversitesi, Sosyal Bilimler Enstitüsü, Balıkesir). http://tez2.yok.gov.tr/ adresinden edinilmiştir. 